\title{
A Review on the Factors Affecting the Learning of Arabic Macro- Skills Among Malay Undergraduate Students
}

\author{
Aliyu Abdullahi ${ }^{1}$, Nurazan Binti Mohmad Rouyan ${ }^{1} \&$ Siti Salwa Mohd Noor ${ }^{1}$ \\ ${ }^{1}$ Center of Arabic Language Studies, Faculty of Languages and Communication, Universiti Sultan Zainal Abidin, \\ Malaysia \\ Correspondence: Aliyu Abdullahi, Center of Arabic Language Studies, Faculty of Languages and Communication, \\ Universiti Sultan Zainal Abidin, Gong Badak Campus, 21300 Kuala Nerus, Terengganu, Malaysia. Tel: 60-1133- \\ 221-092. E-mail: aambyl13@gmail.com
}

Received: May 21, 2018; Accepted: June 17, 2018; Published: June 23, 2018

\begin{abstract}
This research intends to review a number of studies on the factors which might have an influence on the learning of Arabic as second language macro-skills (reading, writing, listening, and speaking) among Malay undergraduate students. The reviewed articles are categorised into four groups: literature related to factors affecting the speaking skills, literature related to factors affecting the writing skills, literature related to factors affecting the listening skills, and literature related to factors affecting the reading skills. However, different empirical studies reviewed confirm many factors have significant correlations with the students' performances in learning Arabic language macro-skills. Such factors are Malay students' attitude towards the Arabic language; the use of Arabic for communication purposes; lack of confidence and teaching techniques. However, some studies account different results. This mixture of results regenerates from diversities in methodology, variables used and the time of the study.
\end{abstract}

Keywords: Arabic language, factors, macro skills, Malay students, second language

\section{Introduction}

Learning a second language is not as simple as learning the mother language (Pinter, 2017). Various studies highlight some issues concerning the difficulties foreign language learners encounter and some suggestions are given based on the skills needed by learners (Yan \& Wan, 2018). Thus, to experience weaknesses in any of the language skills is as equal as having a deficiency in that language (Lightbown, 2016). Hence, in Malaysian context where the Arabic language is learned as a foreign language, both teachers and learners are facing various challenges (Haron, Ahmed, Mamat, \& Rawash, 2016). Various studies relate the problems of learning Arabic in Malaysian context to various constraining factors.

Another challenge facing AFL undergraduate Malaysian learners is lack of exposure to the Arabic language. For the vast majority of the undergraduate students that are learning Arabic as a foreign language in Malaysia are lacking exposure towards Arabic language (Bahraudin, 2017). The use of Arabic language for most of the students is confined to classroom whereas in sometimes lecturers are giving lectures not in the target language but students' mother language. Because of the class time constraint, vocabulary reinforcement is may be one of the causes of students' poor performance across the four language skills.

However, motivation may be one of the constraining factors to Malaysian undergraduate students' performance across the four Arabic language skills. Thus, it could be argued that motivation has real audiences and influence on how foreign language learners learn language skills. As Dörnyei (2001) reiterates that good motivation has a positive effect on foreign language learning. Few studies conducted in Malaysian context focus on motivation like the one carried out by Ainol and Sarudin (2009) which investigate Malaysian motivation towards learning foreign languages in general not Arabic language in particular.

\subsection{Factors Affecting the Listening Skills}

The influence of anxiety in Arabic language learners' environment particularly in foreign language learners' situation is put in to consideration by many researchers (Bahraudin, 2017). However, researchers like Haron et al., (2016) declared that Arabic students with peak language anxiety levels might have low language achievement. Anxiety happens as soon as students come to a motion that they ponder is so intricate or different (Zhang, 2013). 
Though, wan (2016) found that listening ability is tremendously anxiety frustrating mostly when the text is not comprehensible to the learners. Students regularly sensed nervous if listening in the target language for the reason that several factors for example the legality of the listening script (Bahraudin, 2017). Even though unidentified or rigid sentence used in the script, peculiarity of the listening substantial for the environmental factors for instance accent, and learners' lack of self-reliance in their listening ability (Yan \& Wan, 2018).

Adnan, (2011) strained to distinguish the reason for listening anxiety in the Arabic language learning environment and discovered that Arabic language listening anxiety among Malay learners is related with the types of listening sound the learners have to listen to, the method they endure and instructional elements, classroom practices and assessments. To be an effective listener, a student must to be able to strongly and tactically participate in the listening training inside a truncated anxiety learning environment (Sulaiman et al., 2017). Nevertheless, the conclusion on either Arabic listening anxiety generates poor language attainment is still debatable. As a result, a research on listening anxiety is required for the effective teaching of Arabic listening, particularly to foreign language learners (Rahman, Chik, \& Sahrir, 2017).

Furthermore, anxiety is an emotive element that exasperates the learning progression. Moreover, anxiety is associated with negative feelings like fear, exacerbation, doubt, discomfort and pressure (Sulaiman et al., 2017). Foreign language anxiety straightforward effects motivation and produces a destructive response to the language learned (Duxbury, \& Tsai, 2014). The miserable influence of listening anxiety has fortified several researchers to study the origins of listening anxiety. Adnan, (2011) conducted a research with 20 Arabic learners to determine the causes of listening anxiety. He divided listening anxiety into four categories: the story of listening empathetic, listening tools and listening tasks, instructional and communal factors, second language capability and listening concentration. Horwitz, (2016) also claim that characteristics of determination like the quickness or strangeness with the listening contribution and instructional separate factors basically made listening anxiety to the learners. He said again that among the individual factors afraid of disenchantment acted to be allied to learners' mistaken coherent about language knowledge or bad occurrence. Nonetheless, Dewaele, and MacIntyre, (2014). Confirmed the nature of listening influence for instance quickness, intonation and stress, glassy of the manuscript and quantity of terminology, and recognized that they were the commencement foundations of listening anxiety in learning the second language. In addition, Horwitz, (2016) revealed an extra source of anxiety which is the learners' failures to identify the spoken system of a known sound.

Moreover, Yan, \& wang, (2018) indicated that Arabic listening skills problems caused a depressed character in listening skills, and it might affect listening attainment by an assortment of factors like classroom activities, ecological factors and lecturer's issues. Consequently, researches have displayed that there is a highly deleterious success of Arabic listening anxiety. The bases of Arabic listening skills problems are typically addressed as physiognomies of listening contribution, listening tools and responsibilities, absence of self-reliance in understanding spoken Arabic, taking Arabic listening progresses as a responsibility, and perturbing about text intricacy. However, several researchers who explored the relationship between listening anxiety and listening understanding did not find a real association. As, Horwitz, (2016) found the probable connecting relationships between second language listening problems and listening attainment. 150 learners who learned a second language fulfilled the second language listening issues scale and the test two different time with the breach of several months. The result shown that the second language listening problems might influence second language listening achievements. Conversely, second language listening achievements did not occur to effect the second language listening problems critically. So, to completely realize the relationship between listening problems and language achievement additional researches are required to examine the whole vigorous structure, containing listening issues and the learning environment (Yan, \& wang, 2018).

\subsection{Factors Affecting the Speaking Skills}

Most of the studies on the factors affecting the Arabic speaking skill have the same findings. Among them are: apoor vocabulary, b- lack of practice, c- bad learning environment, d- lack of confidence, e- lack of collaboration with Arabic speakers, f- shyness and feeling intimidated (Al-Khasawneh, \& Maher, 2010; Haron et al., 2016; sulaiman et al., 2017; shahrir et al., 2018; Mutar, Mohammad, Khaleel, \& Mohamed, 2018). Researchers offered diverse views on Arabic-suitable environments in schools, particularly outside the classroom. Nafi (1995) narrated that the Arabic language lecturers (IIUM) Matriculation Centre, explained the atmosphere at the (IIUM) as favourable to the improvement of Arabic speaking skills. This became evident ever since the rule that Arabic was to be spoken at all times. Additionally, there were co-curricular activities such as study circles that necessitate the learners to talk in Arabic. Though, these arguments were found to be contradictory with the learners' responses on the same issue. The students mentioned that the environment at the International Islamic University Malaysia was not favourable enough to support the achievements of Arabic speaking skills. 
Mohd, (2002) declared that the school surrounding was encouraging for students to implement speaking Arabic. His assert was based on a study performed in some government and federal religious secondary schools in Melaka, Negeri Sembilan and Selangor. Though, research was contended by Siti, (2006), her results disproved the existence of such environment in schools. She argued that the lack of practice be the core issue. Arabic was mostly used in class meetings and instruction with teachers, as narrated before by Tarmizi (1997); Hasanah (2001); Anida (2003); and Amilrudin (2003). This was also confirmed by Zawawi et al. (2005) who declared that the best environment for encouraging the use of foreign languages was unavailable in Malaysia. The variety of dominance is maintained mostly by the Malay language, the English language and other ethnic languages, for these are the most accepted media of communication in Malaysian society. Foreign language students in Malaysia, particularly the learners of Arabic, are normally unmotivated to employ these foreign languages in communication because of the constant use of their mother tongue, consequently contributing to their weakness in their speaking skills.

The majority of the students do not apply much effort to advance their Arabic speaking skill (Khalid, 2004). According to Amilrudin (2003), this setback is invasive, including even the university students, as they are tremendously shy to speak Arabic, afraid of being ridiculed and blamed for being show-offs. However, he also found that the majority of the students never used extra Arabic equipment apart from the textbook, be it printed or electronic, for example, magazines, newspapers, radio, television, or the internet, in the mission to advance their Arabic speaking skill. Mohd (2005) in other hand, narrated that students in this study carried out many activities to improve their learning, like reading Arabic magazines and books, watching Arabic movies, mastering Arabic vocabularies, answering questions in Arabic, speaking Arabic with friends, asking questions in Arabic, partaking in Arabic language competition. Siti (2006) argued that the students' justification for learning Arabic might be the cause of their weakness in speaking the language. She narrated that students' purpose of learning Arabic was mostly to enable them to understand religious books, reading the Quran, and also reading Arabic literature and poetry.

Ainol and Isarji (2009) exposed from a focus group discussion that the major aim of learning the Arabic language was to comprehend Quran since it is the language of the Quran. Related results were said earlier by Nafi (1995), that the students' main purpose of learning Arabic was to know about Islam, secondly, to arrange for a profession where the Arabic language is necessary, and finally, from the suggestion of relatives and friends, and their special interests. Kaseh, Nil and Zeti (2010) stated that religious inspiration played a significant role in the Muslim learners of Arabic as they affirmed "Muslim learners' were interjected and identified rule so powerfully prejudiced by the religion of Islam, these religious motives with extrinsic beginning have been so internalized by the learners statistically, the items exceed the boundaries between subscales to gather jointly with other religious motives irrespective of the items' formerly hypothesized origins." Nonetheless, all of these need a good command of Arabic grammar and understanding, rather than just the capability to communicate.

The majority of Malay learners they put no effort to produce an Arabic environment that could assist them to increase the Arabic speaking skill. Possibly they do not sense the necessity to use Arabic as a medium of communication for the reason that they are living between the Malays. This setback was stated by Khalid (2004) as he mentioned that most of the students partaken in his study did not put much effort to advance their Arabic speaking skill. Azani et al. (2012) conducted a research at NRSS Kuala Lumpur concerning improving speaking abilities via achievement of hard working engagements in teaching the Arabic language assists the investigators to defeat students' problems in understanding the Arabic language. In contrast, the outcome of the study proves that the learners' problems in speaking abilities through role-play events should be separated to 4 groups; Arabic grammar, phonetic, vocabulary.

Though, learners' approach towards role-play events discovered that learners' contribution is a transitional stage. In conclusion, the researchers discovered that students acted optimistically across the practice of role play in knowing Arabic as it befits student-centred knowledge which provides chances for learners to investigate second language nature according to their experience. Moreover, In understanding the Arabic language as a second language, Bahraudin (2017) discovered that a good number of Malay learners of Arabic have skills of Arabic syntax and lexis, but using it is speaking skills is difficult to them. This predicament happens for many aspects, which include lack of confidence, poor teaching method, the mother tongue influences.

\subsection{Factors Affecting the Reading Skills}

Haron et al., (2016) mentioned various issues as the causes why reading is not encouraged by Malaysian nation as follow: work consumes their time, the impact of the environment, the costs of reading materials which are measured expensive, also the attitude of considering the reading as insignificant. Findings show that a small number of Malay learners of Arabic are eager to put more effort in reading because they do not get pleasure from 
reading the Arabic text, because they assume that reading Arabic text does not promote them in any way or the other, when related to other language like English and Malay language, additionally about time limitations due to the nature of their day to day activities. However, Baba (2007) stated that reading of extra Arabic reading materials apart from the syllabus by undergraduate Malay Arabic learners is very rare while compared to foreign students in Malaysia, specifically, they glance at an average of only thirteen books during three or four years of study. This indicates that most of the Malay students are not performing well in Arabic reading.

Sutarjo (2008) and Siti (2009) discovered that the appliance of SQ3R method could enhance learners' curiosity and ability in the Arabic reading knowledge. This is verified through the escalation in the normal assessment of the Arabic reading grades since the first term up to the third term. The use of SQ3R method besides rises the ability of the Arabic reading understanding which is confirmed by the escalation in total of learners who can produce most important ideas, able of choosing main subjects, competent to arrive at decisions in the Arabic reading, capable to construct subjects summary and distinguish among evidences and sentiments from the Arabic reading manuscript for every term. Findings of the research are not greatly dissimilar from the conclusions of research conducted by Mohd (2009), the major issue which creates different tribulations to learners of Arabic in reading passage can be observed in the students' intention for reading Arabic script. The stumpy proportion of the Arabic learners that read Arabic script for leisureliness indicates their actual assertiveness. The chance of escalating the Arabic language ability and lexis by reading Arabic manuscript throughout free time is merely disregarded or lost. However, reading Arabic script is occurred only for special or compulsory commitments, for example making tasks or searching for solutions.

Most of the reasons mentioned beyond the reading Arabic script are correlated to the abilities of reading understanding. The reason for implementing guidelines of alnahwu and alsarfu emerges to be distinct to script accepting. It seems simply to examine the vowels marked and the accurate phonation of each expression in the manuscript. Though, it is usually famous that the student's reason of accurate accent of expression vowels marked is to know the connotation of a constructed words. Consequently, learners are taught to apply procedures of alnahwu and alsarfu whereas reading Arabic writing to make sure they are capable to understand better expressions and words arrangement as spoken in the sentences of acumen: (The accurate meaning indicates the accurate syntax manifestation). The stage of concern of reading skills and writing skills learners of Arabic language and building orientation to Arabic elements is quiet short. The learners are focusing on Arabic reading script connected to the Islamic religion and their area of study. Even though this circumstance is precise suitable for learners of Islamic religious, but abandoning common reading resources will manipulate their understanding and attentiveness to face a additional demanding peripheral vocabulary. The greatest significant achievement is the restriction on their capability to know a diverse phonological index.

A study similarly shows that learners deficiency referring to customary writing and present Arabic reference paperwork. However, upon enquiring the explanation for this occurrence, many reasons are set, such as lack of chances, simply jaded and tired, incapability to concentrate due to the deafening environment, grind in considering the significance of sentence or words, and also exertion in knowing Arabic manuscript which is typically not vowel marked. Nevertheless, there are some learners who offer the cause for advancement they also say many words in Arabic script are not easy. So the reasons caused them to be more tending to go for an easiest way of learning, fast and simple according to their perceptions, so, they refer to Malay books whichever formerly written in Malay language or interpreted from Arabic. The condition is difficult to the indolent assertiveness learners to refer to a lexicon if vocabularies are strange to them.

This kind of experience is actual disturbing to educators and academic staff since the civilisation of denoting to translated scripts and Malay reference manuscript resolve to the superiority of upcoming F.P.I alumni to failure. Consequently, the graduates created shall be inexpert in understanding the Arabic script, superficial in their spiritual acquaintance also not self-assured to convey information since their knowledge is not originated from foremost bases. Although their reason not to get back to customary books as their sources is because of complexity in knowing the Arabic language in the books is fairly correct. However, it could not be a suitable excuse for learners. They must understand that somewhat authentic and extremely treasured is surely hard to attain.

In this observation, the different complications confronted by the learners in reading Arabic text for example the manuscript of the Arabic language is highly unconventional, the words are seldom originate, understanding of words, and it also vowel less, this should not be the major problems to obstruct the reading the Arabic script. Terminology is infrequently initiate since they rarely use Arabic manuscript. Similarly with the tribulations of the knowing of vocabularies or constructions and script of the Arabic language is very innovative can be conquered by returning to a dictionaries, questioning a lecturer and often reading Arabic manuscript. So all the difficulties can be solved by constant purpose and struggle. 


\subsection{Factors Affecting the Writing Skills}

The Malaysian Ministry of Education (2008) has recognised that essay-writing is the main problem for students to obtain essential marks in the examination. Jaafar (2011) and Ahmad (2003) argue that students' poor performance in writing Arabic results from poor learning method particularly sentences construct. Additionally, studies indicate that writing skill is not a simple task and cannot be simply achieved without any proper practices due to being a difficult cognitive activity that requires 5 main levels: thematic, paragraph, sentence, grammar, and lexical (Lavelle, Smith, \& O'Ryan, 2002). Hidi and Boscolo (2008) stated that there is a disparity between a writer and a reader, as writers invent texts within a restricted situation and time, and not just merely use them.

Because of such problems, students face many writing skills problems and are often disappointed (Scott \& Vitale, 2003). They recognise that these challenges shadow from basic mechanical problems such as spelling, idea, and punctuation to higher cognitive and metacognitive problems. Due to this disturbing issue, it is important that the affecting factors be considered and learned by language teachers and curriculum makers. Different factors influence students' performance in writing as confirmed by many studies.

Boud (2001) confirmed the significance of a teacher as a facilitator in different writing activities, while Witte, Daly, Faigley, \& Koch (1983) say that students themselves want to be taught various kinds of essays effectively. It is stated that the best writing teacher is one who is superior, and has high intellectual level. Earlier studies indicate that teachers' behaviours could lead students to have an intrinsic motivation (Baba, 2007; Senin, 1997). Mohamad (2009) and Haron (2012) stated that the regularity of reading materials has the significant relationship with student achievement and this argument is supported by Jalil (2013) who said that lack of reading materials influence students' writing ability.

\section{Method}

The reviewed literature is categorised into two groups: Productive skills (literature related to factors affecting the speaking skills, \& literature related to factors affecting the writing skills) and Receptive skills (literature related to factors affecting the listening skills, and literature related to factors affecting the reading skills).

\section{Conclusion and Recommendation}

Different empirical studies reviewed confirm many factors have significant correlations with the students' learning of Arabic macro-skills. Regarding speaking skill, most of the studies show the same findings. Among them are: poor vocabulary, lack of practice, lack of confidence. Also, according to the reviewed studies poor teaching and learning techniques from the both side of teachers and students affect the writing skill, and most of the affected portions are spelling, idea, and punctuation. Nevertheless, almost all the studies reviewed indicate that listening anxiety is the major factor affecting the Arabic listening skill, while students' attitude is among the factors affecting reading skills.

Furthermore, this research recommends that Arabic language macro-skills should be learned with the Arabic language as a medium of instructions, especially at tertiary institutions. The authorities should implement the important recommendations given by many researches concerning teachers, students, and curriculum factors. Open dialogue to be created in order to discover practical solutions to the problems of learning Arabic among Malay students.

\section{Summary}

This research reviewed many studies on factors which might have an influence on the learning of Arabic as second language macro-skills (reading, writing, listening, and speaking) among Malay undergraduate students. The paper is structured into four segments. The first segment is the introduction of the study; the second segment is empirical reviews of the literature on productive and receptive skills; the third segment is the summary, and the fourth segment is conclusion and recommendation of the study.

\section{References}

Adnan, M. A. M. (2011). Language learning strategies and self-efficacy belief in Arabic Language learning: a malaysian context. Asean Journal of Teaching and Learning in Higher Education (AJTLHE), 3(2), 48-59.

Ahmad, A. (2003). Arabic writing skills among Malay students. (Unpublished PhD thesis). Malaya University.

Ainol, M., \& Isarji, A. (2009). Motivation to learn a foreign language in Malaysia. GEMA Journalof Language Studies, 9(2), 73-87.

Al-Khasawneh, F. M. S., \& Maher, S. (2010). Writing for academic purposes: Problems faced by Arab postgraduate students of the college of business, UUM. ESP World, 9(2), 1-23. 
Amil-rudin, I. (2003). ArabicLanguage communication strategies among the Malay students: A case study. Unpublished Master's thesis, University of Malaya, Kuala Lumpur.

Anida, A. (2003). Arabic Language learning strategies of the Malay students. Unpublished Master's thesis, University of Malaya, Kuala Lumpur.

A-Shanti, M. S. (2003). al-Maharat al-lughawiyah. Cet. Ke-5. al-Mamlakah al-cArabiyah al-Sacudiyah.

Baba, S. A. (2007). Smart Teaching and Learning Strategies in Prewriting Activities.: National University of Malaysia.

Bahraudin, H. (2017). Strategi dan Teknik Terjemahan Novel Arab dalam Kalangan Pelajar Universiti (Arabic Novel Translation Strategies and Techniques used among University Students). GEMA Online ${ }^{\circledR}$ Journal of Language Studies, 17(4), 72-91. https://doi.org/10.17576/gema-2017-1704-15

Che, O. (2004). Teachers' problems in teaching Arabic Language in government secondary schools in Malaysia. Unpublished Master's thesis, National University of Malaysia, Selangor.

Creswell, J. W. (2007). Qualitative inquiry \& research design: Choosing among five approaches (2nd edn).Thousand Oaks: Sage Publications.

Crow, A. C., \& Crow, L. D. (1983). Educational Psychology for Teachers. Kuala Lumpur: Macmillan.

Dewaele, J. M., \& MacIntyre, P. D. (2014). The two faces of Janus? Anxiety and enjoyment in the foreign language classroom. Studies in Second Language Learning and Teaching, 4(2), 237-274. https://doi.org/10.14746/ssllt.2014.4.2.5

Dörnyei, Z. (2001). New themes and approaches in second language motivation research. Annual Review of Applied linguistics, 21, 43-59. https://doi.org/10.1017/S0267190501000034

Dornyey, Z. (1990). Conceptualizing Motivation in Foreign Language Learning. Language Learning, 40, 45-78. https://doi.org/10.1111/j.1467-1770.1990.tb00954.x

Duxbury, J. G., \& Tsai, L. L. (2014). The effects of cooperative learning on foreign language anxiety: A comparative study of Taiwanese and American universities. International Journal of Instruction, 3(1).

El-khafaifi, H. (2005). Listening comprehension in the Arabic classroom. The Modern Language Journal, 89, 206220. https://doi.org/10.1111/j.1540-4781.2005.00275.x

Examination Board. (2007). Report of Quality Candidates Answer for Arabic Language Paper 2. Malaysian Certificate of Education Report, Ministry of Education, Malaysia.

Harison, M. (2010). Reading instruction theory and practice. Nilai: Penerbit USIM.

Haron, S. C., Ahmed, I. H., Mamat, A., Ahmad, W. R. W., \& Rawash, F. M. M. (2016). Challenges in Learning to Speak Arabic. Journal of Education and Practice, 7(24), 80-85.

Hasanah, Ik-san. (2001). Teaching and learning of Communicative Arabic Language: A study in JAIS secondary religious schools. Unpublished Master's thesis, National University of Malaysia, Selangor.

Horwitz, E. K. (2016). Factor Structure of the Foreign Language Classroom Anxiety Scale: Comment on Park (2014). Psychological reports, 119(1), 71-76. https://doi.org/10.1177/0033294116653368

Horwitz, E. K. (2016). Reflections on Horwitz (1986), "Preliminary evidence for the validity and reliability of a foreign language anxiety scale". TESOL Quarterly, 50(4), 932-935. https://doi.org/10.1002/tesq.295

Ismail, M. (1999). The mastery level of the Arabic Language among students of SMK Pengkalan Chepa. Unpublished Master's thesis, University of Malaya, Kuala Lumpur.

Ismail, Z. (2009). Belajar melalui teknik SQ3R. Retrieved November 2, 2011, from http://tutor.layar.net/mod/forum/discuss.php?d=51

Jaafar, W. N. (2011). Efficiency of Writing Skills among Student Islamic Secondary Class in Kota Setar, Kedah. (Unpublished Master's thesis) National University of Malaysia.

Jalalu-ddin, Y. M., \& Yamat, H. (2011). Teachers' help for Improve Students' Writing Skills. (Unpublished Phd thesis), IIUM.

Johari, M. J. (1994). Teaching Writing Skills in Malay Subject at upper Secondary School. (Unpublished Master's thesis ), Malaysia: National University of Malaysia.

Khalid, M. L. (2004). Speaking skill achievements of religious streamed students. Unpublished Master's thesis, 
University of Malaya.

Lightbown, P. M. (2016). SLA Research and Foreign-Language Teaching. Handbook of Research in Second Language Teaching and Learning, 3, 103.

Mohd, N. (2009). Teknik Membaca Skimming. Retrieved November 1, 2011, from http://www.muhammadnoer.com/2009/07/teknik-membacaskimming/

Mohd. R., \& Abd. R. (2002). Strategi pengajaran Bahasa Arab di SMKA dan SMAP [Arabic Language teaching strategies in SMKA and SMAP]. Master's thesis, National University of Malaysia, Selangor.

Mohd. Z. M. Z. (2005). Arabic Language learning methodology: A case study in Sekolah Agama Raudhah alNazirin, Jerimbong, Jeli, Kelantan]. Unpublished Master's thesis.

Mutar, Q. M., Mohammad, A., Khaleel, M. A., \& Mohamed, R. S. (2018). Investigating the Factors that Affect the Oral Classroom Participation of Arab Postgraduate Students. Journal of Educational and Psychological Researches, (56), 647-661.

Nurul, H. O. (2009). Muqarrar taclim al-lughah al-cArabiyah lil-natiqin bi ghayriha madkhal taqwimi. Kuala Lumpur: IIUM Press.

Pinter, A. (2017). Teaching young language learners. Oxford University Press.

Rahman, T. A. F. T. A., Chik, A. R., \& Sahrir, M. S. (2017). The Use of Documentary Film Text in Developing Arabic Writing Skills: What the Experts Say. LSP International Journal, 4(2).

Sahrir, M. S., Yahaya, M. F., Nasir, M. S., \& Hamid, M. F. A. (2018). Design and Development of Mobile EZArabic. Net for Ubiquitous Learning Among Malaysian Primary School Learners from Experts' Perspective. In Mobile and Ubiquitous Learning (pp. 341-361). Springer, Singapore. https://doi.org/10.1007/978-981-106144-8_20

Shalabi, A. (1980). Taclim al-lughah al-cArabiyah li ghayr al-cArab. Kaherah: Maktabah al-Nahdah al-Misriyah.

Siti, I. S. (2006). The problem of Arabic speaking skill among the students of religious secondary schools in Selangor. (Unpublished Master's thesis). IIUM.

Siti, K. (2009). Kajian upaya meningkatkan kemampuan membaca pemahaman dengan metode SQ3R pada siswa kelas X. 3 SMA, Sumberlawang, Surakarta.

Sulaiman, R. H. R., Din, N. M. N., Awang, R. E. N., Mustafa, Z., Noruddin, N., \& Talib, M. T. (2017). RolePlaying Technique in Teaching Arabic Communication: A Case Study at Universiti Sultan Zainal Abidin in Malaysia. International Journal of Academic Research in Business and Social Sciences, 7(10), 309-318. https://doi.org/10.6007/IJARBSS/v7-i10/3379

Surapa (2011). Strategies for coping with face to face oral communication factors employed by Thai university students. GEMA Online Journal of Language Studies, 11(3), 83-96.

Sutarjo, J. C. (2008). Penerapan strategi untuk meningkatkan kemampuan membaca interpretatif dalam bahasa Arab. Tapis, 8(1), Januari.

Tanveer, M. (2007). Investigation of the problems that cause language anxiety for ESL/EFL learners in learning speaking skills and the influence it casts on communication in the second language. Unpublished Master's thesis, University of Glasgow.

Tarmizi A. (1997). The teaching and learning of Arabic speaking skill: A case study in SMKA. Unpublished Master's thesis, University of Malaya, Kuala Lumpur.

Yan, J. X., Pan, J., \& Wang, H. (2018). Learner Variables and Problems Perceived by Students: An Investigation of a College Interpreting Programme in China. In Research on Translator and Interpreter Training (pp. 123146). Springer, Singapore. https://doi.org/10.1007/978-981-10-6958-1

Zawawi, M. Sukki, O. Alif, R., \& Sanimah, H. (2005). Masalah Problems of Arabic and Japanese speaking skills: A comparative study. (Unpublished Master's thesis), IIUM.

\section{Copyrights}

Copyright for this article is retained by the author(s), with first publication rights granted to the journal.

This is an open-access article distributed under the terms and conditions of the Creative Commons Attribution license (http://creativecommons.org/licenses/by/4.0/). 